\title{
Range extension of the invasive Potamopyrgus antipodarum (Gray, 1843) (Gastropoda, Tateidae) in Chile, and a summary of its distribution in the country
}

\author{
Gonzalo A. Collado ${ }^{1,2}$, Carmen G. Fuentealba ${ }^{1}$ \\ 1 Departamento de Ciencias Básicas, Facultad de Ciencias, Universidad del Bío-Bío, Avenida Andrés Bello 720, Chillán, 3800708, Chile. 2 Grupo \\ de Biodiversidad y Cambio Global, Universidad del Bío-Bío, Avenida Andrés Bello 720, Chillán, 3800708, Chile. \\ Corresponding author: Gonzalo A. Collado,gcollado@ubiobio.cl
}

\begin{abstract}
The New Zealand mudsnail Potamopyrgus antipodarum (Gray, 1843) has been considered as one of the most invasive mollusks worldwide and recently was listed among the 50 most damaging species in Europe. In the present paper, we report for the first time the presence of $P$. antipodarum in the Maule river basin, Chile. The identity of the species was based on anatomical microdissections, scanning electron microscopy comparisons, and DNA barcode analysis. This finding constitutes the southernmost record of the species until now in this country and South America.
\end{abstract}

\section{Keywords}

Alien species, DNA barcode, cryptic species, invasive mollusks, Maule River, range distribution.

\section{Introduction}

Biological invasions may cause a series of effects on invaded ecosystems such as economic damage, alterations of habitats and biotopes, threats to biodiversity, and harm to human health. Although habitat loss is the main cause of species extinctions in the modern age (Tollefson 2019), biological invasions nowadays represent one of the main causes of biodiversity loss (e.g. Gordon 1998; Wilcove et al. 1998; Bax et al. 2003; Lodge and ShraderFrechette 2003; Juliano and Lounibos 2005).

The New Zealand mudsnail (NZMS), Potamopyrgus antipodarum (Gray, 1843), is one of the most successful and widespread invasive freshwater mollusks in the world (Son 2008; Alonso and Castro-Díez 2008; Butkus et al. 2012), and in fact, it was recently listed among the 50 most damaging species in Europe (Nentwig et al. 2017). The native range of this species is New Zealand and adjacent islands (Winterbourn 1970, 1972; Ponder 1988). Now, the NZMS has invaded brackish and freshwater ecosystems in several countries in Asia, Australia, Europe, and North and South America (e.g. Ponder 1988; Bowler 1991; Shimada and Urabe 2003; Levri et al. 2007; Radea et al. 2008; Butkus et al. 2012; Hamada et al. 2013; Collado 2014).

The first records of the NZMS in North America were made in the Snake River, Idaho, in late 1980s and early 1990s (Bowler 1991; Bowler and Frest 1992). In South America, Collado (2014) first discovered NZMS in two places in Choapa river basin and two others in Maipo river basin in the central-north part of Chile. However, NZMS was present earlier in Chile but it was overlooked 
by Collado et al. (2011) and Collado and Méndez (2011), who ascribed part of their samples to the genus Heleobia Stimpson, 1865. Subsequently, NZMS has been reported from additional localities in Chile, with the southernmost record from Lo Carreño irrigation canal in the Rapel river basin (Collado 2016; Collado et al. 2019a, 2019b).

The NZMS can spread to new habitats through passive and active dispersal mechanisms and, although it is highly tolerant to a variety of physicochemical water conditions (Dorgelo 1987; Poirier 2013), it prefers freshwater environments rather than brackish water. In laboratory experiments, the NZMS exhibited avoidance behaviors to predatory fishes, a trait that can help the spread of the species (Levri et al. 2017).

The objective of this paper is to report a new record of the invasive NZMS in Maule River, central Chile, the southernmost record known, until now, in this country and in South America.

\section{Methods}

In March 2019, five localities were prospected to collect freshwater snails in central Chile: Claro River $\left(35^{\circ}\right.$ $\left.25^{\prime} 12.03^{\prime \prime} \mathrm{S}, 071^{\circ} 40^{\prime} 57.36^{\prime \prime} \mathrm{W}\right)$ and Maule River (35 $33^{\prime}$ $\left.12.69^{\prime \prime} \mathrm{S}, 071^{\circ} 41^{\prime} 56.45^{\prime \prime} \mathrm{W}\right)$ in Maule river basin, Maule Region, and Cato River (36 $\left.33^{\prime} 26.68^{\prime \prime} \mathrm{S}, 072^{\circ} 02^{\prime} 39.87^{\prime \prime} \mathrm{W}\right)$, the irrigation canal La Luz $\left(36^{\circ} 35^{\prime} 31.64^{\prime \prime} \mathrm{S}, 072^{\circ} 04^{\prime}\right.$ $\left.13.31^{\prime \prime} \mathrm{W}\right)$, and Las Toscas stream $\left(36^{\circ} 35^{\prime} 34.89^{\prime \prime} \mathrm{S}, 072^{\circ}\right.$ $\left.03^{\prime} 38.62^{\prime \prime} \mathrm{W}\right)$ in Itata river basin, Nuble Region. The snails were sampled using a hand sieve and stored in absolute ethanol. The shell and operculum were photographed and measured using a Motic SMZ-168 Stereomicroscope equipped with a Moticam 2000 camera. For taxonomic identification, morphological and microstructural features were studied following Collado et al. (2019a), including protoconch, operculum and radula, which were observed using scanning electron microscopy (SEM) (Hitachi SU3500). The reproductive strategy of snails was studied by microdissections. A DNA barcode analysis (Hebert et al. 2003) was performed in the BLASTn section of the GenBank database after sequencing the cytochrome $\mathrm{c}$ oxidase 1 (COI) gene based on the molecular methods performed by Collado (2014). Voucher specimens of the NZMS were deposited at the collection housed in Laboratorio de Malacología y Sistemática Molecular, Universidad del Bío-Bío, Chillán, Chile (LMSM-UBB) and at Museo de Ciencias Naturales Profesor Pedro Ramírez Fuentes (MCNPPRF), Chillán, Chile (Acta de Ingreso 157).

\section{Results}

Sampling was positive for the NZMS Potamopyrgus antipodarum only in Maule River. The species was found in syntopy with specimens of the gastropod genera Potamolithus Pilsbry, 1896 (Tateidae), Chilina Gray, 1828 (Chilinidae), and Physa Draparnaud, 1801 (Physidae).

\section{Taxonomic account}

Superfamily Truncatelloidea Gray, 1840

Family Tateidae Thiele, 1925

Genus Potamopyrgus Stimpson, 1865

\section{Potamopyrgus antipodarum (Gray, 1843)}

Materials examined. Chile • 1 , 4.7 mm; Maule Region, Maule river basin, Maule River; 35³3'12.69"S, 07141'57.04"W; 96 m a.s.1., 3 Mar. 2019; G.A. Collado leg.; GenBank: MG779236; PaMR1-LMSM-UBB; MCNPPRF-CC 157-2 (radula), MCNPPRF-CC 157-4 (protoconch) - 29, $2.8 \mathrm{~mm}$; same collection data as for preceding; GenBank: MG779236; PaMR2-LMSMUBB; MCNPPRF-CC 157-3 (operculum) • 3ㅇ, 2.6 mm; same collection data as for preceding; PaMR3-LMSMUBB; MCNPPRF-CC 157-1 (shell).

Identification. NZMS are similar in shell morphology to species of the genus Heleobia and Potamolithus (Collado et al. 2019a, 2019b), which include several native species in Chile. Species-specific identification was performed after observation of the protoconch and radula, which differ among genera (Collado et al. 2019a).

Morphology. The shell of the NZMS is ovate-conic (Fig. 1A-D), not umbilicated, with 5-6 whorls, aperture ovate. Protoconch having ca 1.2 whorls (Fig. 1E, F). Operculum corneous, bright brown-orange, solid, with white smear (Fig. 1G-J). Radula taenioglossan (general formula: 3-1-3), composed by seven teeth on each row: two marginal teeth (external and internal) and a lateral tooth located on each side of the central tooth (Fig. 1K, L). Central tooth with five lateral cusps on each side of a larger median cusp and three decreasing pairs of basal cusps (Fig. 1L). Distal section of the external marginal teeth free (flange well developed).

DNA barcoding. Two identical partial COI sequences of 639 bp from PaMR1-LMSM-UBB and PaMR2-LMSMUBB were obtained. The BLASTn analysis comparing this haplotype against GenBank database found $100 \%$ identity with sequences of $P$. antipodarum previously published (Ponder et al. 2008; Neiman et al. 2010; Hamada et al. 2013; Collado et al. 2014, 2019a, 2019 b), confirming the taxonomic assignment based on morphology.

Distribution. Although the distribution of the NZMS in Chile is not continuous regarding its absence in some contiguous basins, the species is present in five political regions of the country, specifically from the Coquimbo to Maule regions. With the new record provided here, the occurrence of the NZMS in Chile reaches 19 localities (Collado 2014, 2016; Collado et al. 2019a, 2019b; present study) (Fig. 2, Table 1).

\section{Discussion}

Our integrative study using freshwater snails collected in Maule River, central Chile, revealed the occurrence of 


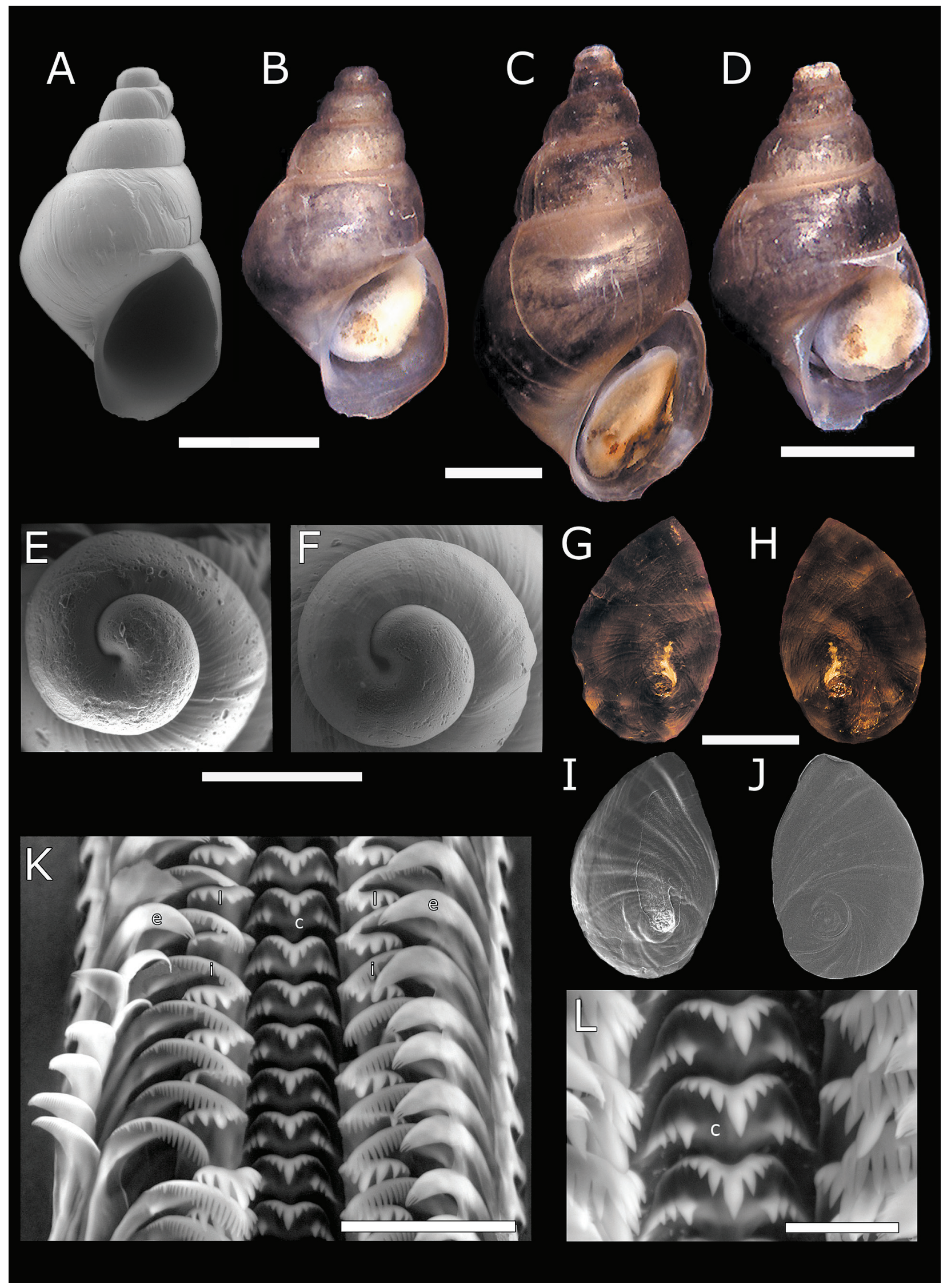

Figure 1. Potamopyrgus antipodarum (Gray, 1843), Maule River, central Chile. A. Shell of specimen PaMR1-LMSM-UBB observed with SEM. B-D. Shells of specimens PaMR1-LMSM-UBB, PaMR2-LMSM-UBB and PaMR3-LMSM-UBB, respectively, observed with stereomicroscope. E, F. Protoconchs of two individuals. G, H. Operculum observed with stereomicroscope (internal and external view, respectively). I, J. Operculum observed with SEM (internal and external view, respectively). K. Anterior section of the radula. L. Three central teeth of the radula. Abbreviations: $\mathrm{c}=$ central tooth; $\mathrm{e}=$ external marginal tooth; $\mathrm{i}=$ internal marginal tooth; l: lateral tooth. Scale bars: $\mathrm{A}-\mathrm{D}=1 \mathrm{~mm} ; \mathrm{E}$, $\mathrm{F}=300 \mu \mathrm{m} ; \mathrm{G}-\mathrm{J}=500 \mu \mathrm{m} ; \mathrm{K}=50 \mu \mathrm{m} ; \mathrm{L}=20 \mu \mathrm{m}$. 


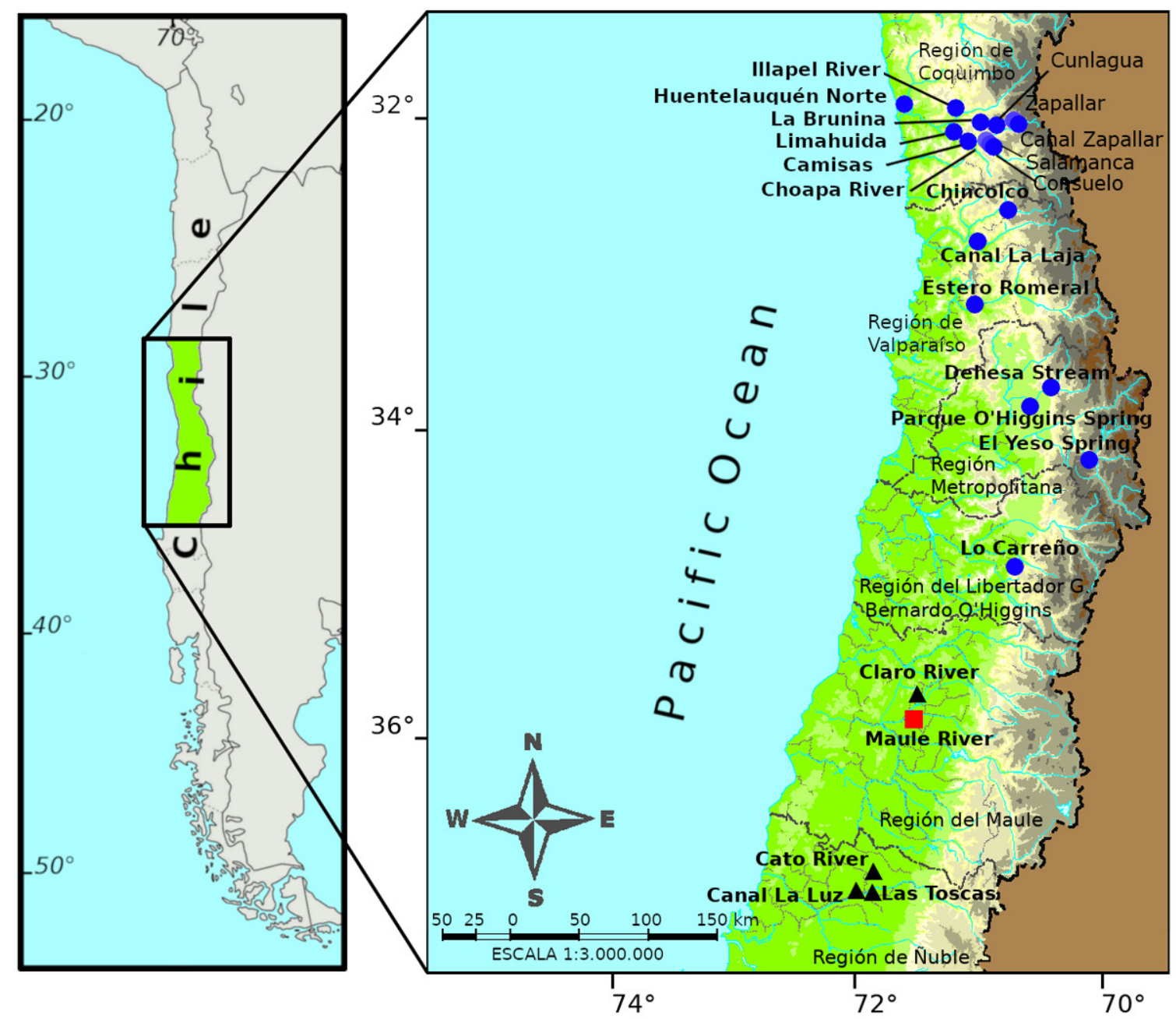

Figure 2. Geographic records of the invasive freshwater snail Potamopyrgus antipodarum (Gray, 1843) in Chile. Square: new record of the species; circle: previous records obtained from the literature (Collado 2014, 2016; Collado et al. 2019a, 2019b); triangles: localities where $P$. antipodarum was not found.

the highly invasive NZMS Potamopyrgus antipodarum. This finding represents the first record of the species in the Maule River, expands its southern distribution to this locality and, in turn, constitutes the southernmost record of the species known until now in South America. The previous southernmost record was Lo Carreño in Rapel river basin, O'Higgins Region (Collado et al. 2019a, 2019b).

As aforementioned, the NZMS is an effective invasive species and niche modeling studies recently published predict a future expansion of the species distribution worldwide (Alexandre da Silva et al. 2019). With respect to South America, suitable areas for the invasion of the NZMS have been predicted in Argentina, Bolivia, Brazil, Colombia, Ecuador, Peru, and southern Chile, encompassing near 80 protected areas. Specifically, the localities identified in Chile are Bio-Bio River (Reserva Nacional Altos de Pemehue) and Laguna del Laja (National Park Laguna del Laja) in Bio-Bio Region, Lago Llanquihue (Biological Reserve Bosques Templados Lluviosos) in Los Lagos Region, and Lago Ranco (Biological Reserve Bosques Templados Lluviosos) in Los Rios Region. Besides, the models suggest that with temperature and precipitation increase predicted by the end of the century, environmental conditions will be even more conducive to the establishment of the NZMS (Alexandre da Silva et al. 2019).

Specimens of the NZMS were found in a recreational riverbank in Maule River. This locality is used as a common watering place by people during the summer, and the introduction of the NZMS through this activity to this watercourse appears rather feasible. However, although not disposable, the species was not found in two localities prospected in the present study that are also used as watering places (Claro and Cato rivers), questioning this mechanism. It is important to note that the NZMS can be introduced to new places by a variety of natural and non-natural vectors (Ribi 1986; Bowler 1991; Zaranko et al. 1997; Richards et al. 2001; Alonso and CastroDiez 2008), making the mechanism of introduction quite speculative. Until now, the cause of introduction of the NZMS to Chile has not been established. Letelier et al. (2007) have suggested that the most likely mechanism of introduction of invasive aquatic species in the country is the aquarium trade. 
Table 1. Records of Potamopyrgus antipopdarum in Chile.

\begin{tabular}{|c|c|c|c|c|}
\hline Basin/locality & System & Latitude (S) & Longitude (W) & Source \\
\hline \multicolumn{5}{|l|}{ Choapa river basin } \\
\hline Chalinga River (Salamanca) & River & $31^{\circ} 46^{\prime} 15.61^{\prime \prime}$ & $070^{\circ} 59^{\prime} 05.09^{\prime \prime}$ & Collado 2014 \\
\hline Consuelo Stream & Stream & $31^{\circ} 46^{\prime} 45.00^{\prime \prime}$ & $070^{\circ} 57^{\prime} 47.30^{\prime \prime}$ & Collado 2014 \\
\hline Choapa River & River & $31^{\circ} 46^{\prime} 58.10^{\prime \prime}$ & $070^{\circ} 58^{\prime} 27.30^{\prime \prime}$ & Collado et al. 2019a \\
\hline Cunlagua & River & $31^{\circ} 44^{\prime} 02.70^{\prime \prime}$ & $070^{\circ} 53^{\prime} 17.80^{\prime \prime}$ & Collado et al. 2019a \\
\hline La Brunina & Irrigation canal & $31^{\circ} 44^{\prime} 23.20^{\prime \prime}$ & $070^{\circ} 57^{\prime} 12.80^{\prime \prime}$ & Collado et al. 2019a \\
\hline Zapallar & River & $31^{\circ} 41^{\prime} 59.40^{\prime \prime}$ & $070^{\circ} 45^{\prime} 13.00^{\prime \prime}$ & Collado et al. 2019a \\
\hline Canal Zapallar & Irrigation canal & $31^{\circ} 42^{\prime} 32.90^{\prime \prime}$ & $070^{\circ} 45^{\prime} 10.30^{\prime \prime}$ & Collado et al. 2019a \\
\hline Camisas Stream & Stream & $31^{\circ} 46^{\prime} 13.90^{\prime \prime}$ & $071^{\circ} 03^{\prime} 57.90^{\prime \prime}$ & Collado et al. 2019a \\
\hline Illapel River & River & $31^{\circ} 37^{\prime} 55.30^{\prime \prime}$ & $071^{\circ} 09^{\prime} 20.30^{\prime \prime}$ & Collado et al. 2019a \\
\hline Limahuida Stream & Stream & $31^{\circ} 45^{\prime} 58.00^{\prime \prime}$ & $071^{\circ} 09^{\prime} 24.70^{\prime \prime}$ & Collado et al. 2019a \\
\hline Huentelauquén Norte & Irrigation canal & $31^{\circ} 36^{\prime} 43.39^{\prime \prime}$ & $071^{\circ} 31^{\prime} 29.29^{\prime \prime}$ & Collado et al. 2019a \\
\hline \multicolumn{5}{|l|}{ Petorca basin } \\
\hline Chincolco & Irrigation canal & $32^{\circ} 13^{\prime} 20.36^{\prime \prime}$ & $070^{\circ} 50^{\prime} 07.11^{\prime \prime}$ & Collado et al. 2019a \\
\hline \multicolumn{5}{|l|}{ Ligua basin } \\
\hline Canal La Laja & Irrigation canal & $32^{\circ} 25^{\prime} 28.91^{\prime \prime}$ & $071^{\circ} 3^{\prime} 44.86^{\prime \prime}$ & Collado 2016 \\
\hline \multicolumn{5}{|l|}{ Aconcagua basin } \\
\hline Estero Romeral & Irrigation canal & $32^{\circ} 49^{\prime} 55.12^{\prime \prime}$ & $071^{\circ} 5^{\prime} 46.52^{\prime \prime}$ & Collado 2016 \\
\hline \multicolumn{5}{|l|}{ Maipo basin } \\
\hline Dehesa Stream & Stream & $33^{\circ} 22^{\prime} 02.00^{\prime \prime}$ & $070^{\circ} 31^{\prime} 15.00^{\prime \prime}$ & Collado 2014 \\
\hline Parque $0^{\prime}$ Higgins Spring & Spring & $33^{\circ} 28^{\prime} 06.22^{\prime \prime}$ & $070^{\circ} 39^{\prime} 38.31^{\prime \prime}$ & Collado 2014 \\
\hline El Yeso Spring & Spring & $33^{\circ} 48^{\prime} 34.67^{\prime \prime}$ & $070^{\circ} 12^{\prime} 37.00^{\prime \prime}$ & Collado et al. 2019b \\
\hline \multicolumn{5}{|l|}{ Rapel basin } \\
\hline Lo Carreño & Irrigation canal & $34^{\circ} 36^{\prime} 45.00^{\prime \prime}$ & $070^{\circ} 55^{\prime} 47.80^{\prime \prime}$ & Collado et al. 2019b \\
\hline \multicolumn{5}{|l|}{ Maule river basin } \\
\hline Maule River & River & $35^{\circ} 33^{\prime} 12.69^{\prime \prime}$ & $071^{\circ} 41^{\prime} 57.04^{\prime \prime}$ & Present study \\
\hline
\end{tabular}

Invasive populations of the NZMS are composed almost exclusively by parthenogenetic females (Gangloff 1998; Butkus et al. 2012) and the introduction of a single female may spread the species in a new ecosystem (Cheng and LeClair 2011; Poirier 2013). In invaded habitats, the NZMS can reach astonishing densities such us 500,000800,000 individuals $/ \mathrm{m}^{2}$ (Richards 2002; Dorgelo 1987) and, in some places, may compete with, displace, and possibly lead native fauna to extinction (Richards et al. 2001; Richards 2002; Collado et al. 2019a, 2019b). The spreading of the species is also of concern because it can transmit trematode parasites (Morley 2008). In Chile, management programs to mitigate the expansion of the NZMS has not been applied despite the potential damage it can cause after arrival.

\section{Acknowledgements}

We thank Cristian Suárez for taking SEM photographs. We also are grateful to Dr Roberto Vogler and Dr Rodrigo Salvador for improving the manuscript. This paper was supported by Proyecto DIUBB 193309 3/R.

\section{Authors' Contributions}

GAC conceived the paper, collected data, and made morphological and molecular study. CGF edited photographs and prepared voucher materials. GAC and CGF wrote the manuscript.

\section{References}

Alexandre da Silva MV, Nunes Souza JV, de Souza JRB, Vieira LM (2019) Modelling species distributions to predict areas at risk of invasion by the exotic aquatic New Zealand mudsnail Potamopyrgus antipodarum (Gray 1843). Freshwater Biology 64: 15041518. https://doi.org/10.1111/fwb.13323

Alonso A, Castro-Diez P (2008) What explains the invading success of the aquatic mud snail Potamopyrgus antipodarum (Hydrobiidae, Mollusca)? Hydrobiologia 614: 107-116. https://doi.org/10. 1007/s10750-008-9529-3

Bax N, Williamson A, Aguero M, Gonzalez E, Geeves W (2003) Marine invasive alien species: a threat to global biodiversity. Marine Policy 27: 313-323. https://doi.org/10.1016/s0308-597x(03) 00041-1

Bowler PA (1991) The rapid spread of the freshwater hydrobiidae snail Potamopyrgus antipodarum (Gray) in the Middle Snake River, southern Idaho. Proceedings of the Desert Fishes Council 21: 173-182.

Bowler PA, Frest TJ (1992) The non-native snail fauna of the Middle Snake River, Southern Idaho. Proceedings of the Desert Fishes Council 23: 28-44.

Butkus R, Šidagytė E, Arbačiauskas K (2012) Two morphotypes of the New Zealand mud snail Potamopyrgus antipodarum (J.E. Gray, 1843) (Mollusca: Hydrobiidae) invade Lithuanian lakes. Aquatic Invasions 7 (2): 211-218. http://doi.org/10.3391/ai.2012.7.2.007

Cheng YW, LeClair LL (2011) A quantitative evaluation of the effect of freezing temperatures on the survival of New Zealand mudsnails (Potamopyrgus antipodarum Gray, 1843), in Olympia Washington's Capitol Lake. Aquatic Invasions 6 (1): 47-54. https://doi.org/10.3391/ai.2011.6.1.06

Collado GA (2014) Out of New Zealand: molecular identification of the highly invasive freshwater mollusk Potamopyrgus antipodarum (Gray, 1843) in South American. Zoological Studies 53: 70. https://doi.org/10.1186/s40555-014-0070-y 
Collado GA (2016) Filling the gap: New records of the invasive New Zealand Mudsnail Potamopyrgus antipodarum in Central Chile. Journal of Zoology Studies 3: 13-19.

Collado GA, Méndez MA (2011) Estrategias reproductivas y tipos de desarrollo en especies endémicas del género Heleobia Stimpson, 1865 (Caenogastropoda: Cochliopidae) de Chile. Amici Molluscarum (Número especial): 67-71

Collado GA, Méndez MA, Letelier S, Veliz D, Sabando MC (2011) Morfología peniana y taxonomía del género Heleobia Stimpson, 1865 en Chile junto a una revisión de los ejemplares tipo del Museo Nacional de Historia Natural de Chile. Amici Molluscarum (Número Especial): 49-58.

Collado GA, Vidal MA, Aguayo KP, Méndez MA, Valladares MA Cabrera FJ, Pastenes L, Gutiérrez Gregoric DE, Puillandre N (2019a) Morphological and molecular analysis of cryptic native and invasive freshwater snails in Chile. Scientific Reports 9: 7846. https://doi.org/10.1038/s41598-019-41279-x

Collado GA, Aguayo KP, Cazzaniga NJ, Gutiérrez Gregoric DE, de Lucía M, Haase M (2019b) Systematic evaluation of cryptic freshwater snails from central Chile, including the enigmatic Littoridina santiagensis (Gastropoda, Truncatelloidea). European Journal of Taxonomy 524: 1-15. https://doi.org/10.5852/ejt.2019.524

Dorgelo J (1987) Density fluctuations in populations (1982-1986) and biological observations of Potamopyrgus jenkinsi in two trophically differing lakes. Hydrobiological Bulletin 21: 95-110. https:// doi.org/10.1007/BF02255459

Gangloff MM (1998) The New Zealand Mud Snail in western North America. Aquatic Nuisance Species Digest 2: 25-30.

Gordon DR (1998) Effects of invasive, non-indigenous plant species on ecosystem processes: lessons from Florida. Ecological Applications 8: 975-989. https://doi.org/10.1890/1051-0761 (1998)008[0975:eoinip]2.0.co;2

Hamada K, Tatara Y, Urabe M (2013) Survey of mitochondrial DNA haplotypes of Potamopyrgus antipodarum (Caenogastropoda: Hydrobiidae) introduced into Japan. Limnology 14 (3): 223-228. https://doi.org/10.1007/s10201-013-0405-0

Hebert PDN, Cywinska A, Ball SL, Dewaard JR (2003) Biological identifications through DNA barcodes. Proceedings of the Royal Society B: Biological Sciences 270: 313-321. https://doi.org/10. 1098/rspb.2002.2218

Juliano SA, Lounibos LP (2005) Ecology of invasive mosquitoes: effects on resident species and on human health. Ecology Letters 8 558-574. https://doi.org/10.1111/j.1461-0248.2005.00755.x

Letelier S, Ramos A, Huaquín L (2007) Moluscos dulceacuícolas exóticos en Chile. Revista Mexicana de Biodiversidad 78: 9-13.

Levri EP, Kelly AA, Love E (2007) The invasive New Zealand Mud Snail (Potamopyrgus antipodarum) in lake Erie. Journal of Great Lakes Research 33: 1-6. https://doi.org/10.3394/0380-1330(2007) 33[1:tinzms]2.0.co;2

Levri EP, Landis S, Smith B, Colledge E, Metz E, Li X (2017) Variation in predator-induced behavioral changes in introduced and native populations of the invasive New Zealand mud Snail (Potamopyrgus antipodarum Gray 1843). Aquatic Invasions 12: 499-508. https://doi.org/10.3391/ai.2017.12.4.07

Lodge DM, Shrader-Frechette K (2003) Nonindigenous species: ecological explanation, environmental ethics, and public policy. Conservation Biology 17: 31-37. https://doi.org/10.1046/j.15231739.2003.02366.x

Morley NJ (2008) The role of the invasive snail Potamopyrgus antipodarum in the transmission of trematode parasites in Europe and its implications for ecotoxicological studies. Aquatic Sciences Research Across Boundaries 70: 107-114. https://doi.org/10.1007/ s00027-007-7052-7

Neiman M, Hehman G, Miller JT, Logsdon JM Jr., Taylor DR (2010) Accelerated mutation accumulation in asexual lineages of a freshwater snail. Molecular Biology and Evolution 27 (4): 954-963. https://doi.org/10.1093/molbev/msp300

Nentwig, W, Bacher S, Kumschick S, Pyšek P, Vilà M (2017) More than "100 worst" alien species in Europe. Biological Invasions 20 (6): 1611-1621. https://doi.org/10.1007/s10530-018-1671-x

Poirier J (2013) New Zealand Mudsnail surveys at national wildlife refuges within the Lower Columbia river basin 2012. Columbia River Fisheries Program Office Annual Report. United States Fish and Wildlife Service 1-24.

Ponder WF (1988) Potamopyrgus antipodarum, a molluscan coloniser of Europe and Australia. Journal of Molluscan Studies 54 (3): 271-286. https://doi.org/10.1093/mollus/54.3.271

Ponder WF, Wilke T, Zhang W-H, Golding RE, Fukuda H, Mason RAB (2008) Edgbastonia alanwillsi n. gen and n. sp. (Tateinae: Hydrobiidae s.1.: Rissooidea: Caenogastropoda), a snail from an artesian spring group in western Queensland, Australia, convergent with some Asian Amnicolidae. Molluscan Research 28 (2): 89-106.

Radea C, Louvrou I, Economou-Amilli A (2008) First record of the New Zealand Mud Snail Potamopyrgus antipodarum J.E. Gray 1843 (Mollusca: Hydrobiidae) in Greece-notes on its population structure and associated microalgae. Aquatic Invasions 3: 341344. https://doi.org/10.3391/ai.2008.3.3.10

Ribi G (1986) Within-lake dispersal of the prosobranch snails, Viviparus ater and Potamopyrgus jenkinsi. Oecologia 69: 60-63. https:// doi.org/10.1007/bf00399038

Richards DC (2002) The New Zealand mudsnail invades the western United States. Aquatic Nuisance Species Digest 4 (4): 42-44.

Richards DC, Cazier LD, Lester GT (2001) Spatial distribution of three snail species, including the invader Potamopyrgus antipodarum, in a freshwater spring. Western North American Naturalist 61: 375-380.

Shimada K, Urabe M (2003) Comparative ecology of the alien freshwater snail Potamopyrgus antipodarum and the indigenous snail Semisulcospira spp. Venus 62: 39-53.

Son MO (2008) Rapid expansion of the New Zealand Mud Snail Potamopyrgus antipodarum (Gray, 1843) in the Azov-Black Sea Region. Aquatic Invasions 3: 335-340. https://doi.org/10.3391/ai. 2008.3.3.9

Tollefson J (2019) Humans are driving one million species to extinction. Nature 569: 171. https://doi.org/10.1038/d41586-019-01448-4

Wilcove DS, Rothstein D, Dubow J, Phillips A, Losos E (1998) Quantifying threats to imperiled species in the United States. BioScience 48: 607-615.

Winterbourn MJ (1970) The New Zealand species of Potamopyrgus (Gastropoda: Hydrobiidae). Malacologia 10: 283-321.

Winterbourn MJ (1972) Morphological variation of Potamopyrgus jenkinsi (Smith) from England and a comparison with the New Zealand species, Potamopyrgus antipodarum (Gray). Proceedings of the Malacological Society of London 40: 133-145. https:// doi.org/10.1093/oxfordjournals.mollus.a065210

Zaranko DT, Farara DG, Thompson FG (1997) Another exotic mollusc in the Laurentian Great Lakes: the New Zealand native Potamopyrgus antipodarum (Gray 1843) (Gastropoda, Hydrobiidae). Canadian Journal of Fisheries and Aquatic Sciences 54: 809-814. https://doi.org/10.1139/f96-343 